\title{
A NEW CERAMIC CASTING MOLD MADE BY GEL CASTING USING SILICA SOL AS A BINDER
}

\author{
Mahmoud F. Zawrah ${ }^{(1)}$, Sayed A. Abdullah ${ }^{(2)}$, Reham M. Khattab ${ }^{(1)}$, Ibrahim M. \\ Ibrahim $^{(2)}$, Waleed F. Youssef ${ }^{(3)}$ \\ (1) National Research Center, Department of Ceramics. \\ (2) Shoubra Faculty of Engineering, Benha University, Department of Mechanical \\ Engineering. \\ (3) Faculty of Engineering, Sinai University, Department of Mechanical Engineering.
}

\begin{abstract}
This Paper presents a new ceramic casting mold made by gel casting using silica sol as a binder. The new ceramic mold is consisted of an aluminamullite-zirconia matrix with the ratios of $38.332 \mathrm{wt}$ \% alumina, $34.378 \mathrm{wt}$ \% mullite, and $27.294 \mathrm{wt}$ \% zirconia respectively, the slurry is mixed then the gelling agent is added and poured into the pattern. After gelation the mold is extracted and left to dry, then sintered. There are three main defects appear in the mold fabrication process. The $1^{\text {st }}$ defect is the mold cracking, as a result of forced shrinkage of mold into pattern. The $2^{\text {nd }}$ defect is the bad gelation behavior of mold, as a result of non equal gelling time. The last defect is mold surface cracks, due to increased silica ratio added to the mixture. As zirconia increased the bulk density and apparent porosity is increased, leading to higher mold permeability which is important to eliminate trapping of residual gases. The increased zirconia content decreases the micro hardness and the cold crushing strength, but increases the thermal shock resistance due to phase transformation during sintering. The ceramic mold is applicable for nodular cast iron so that the mold is hard enough to withstand the forces of spheroidal graphite formation when nodular cast iron is poured into the ceramic mold. The surface roughness no. of metal cast into ceramic mold is $0.582 \mu \mathrm{m}$, while of the metal cast into sand mold is $5.187 \mu \mathrm{m}$.
\end{abstract}

Keywords: Silica Sol; Ceramic Molds; Gel Casting; Precision Casting; Silica Bearing Binders.

\section{INTRODUCTION}

Ceramic molding techniques are based on proprietary that employ permanent patterns and fine-grain zircon and calcined, high-alumina mullite slurries for molding (Piwonka, 1998). A slip consisting of highly refractory substances is poured around the pattern (Böllinghaus et al., 2009), which incorporates gates and risers and is mounted on a match plate (Bralla, 2007). These 
substances harden by chemical reaction (Böllinghaus et al., 2009). The pattern is removed after gelation but before it sets completely (Bralla, 2007). After removing the pattern, the ceramic is fired or skin-dried (Böllinghaus $\boldsymbol{e t}$ al., 2009). Ceramic mold casting is also known as cope and drag investment casting (Jack, 2001). Several refractory materials, as fused silica, fused alumina, tabular alumina, fused or sintered alumina silicates, zirconium silicate and quartz sands were used in ceramic mold industry (Mills, 1992). There are three main processes in ceramic mold making; all ceramic mold process (Piwonka, 1998), Shaw process, and Unicast process (Beeley, 2001). Ceramic mold industries are interconnected and linked to new methods of engineering ceramics formation. Gel Casting is one of the most important of these methods, which strongly developed in recent years. Gel casting is an attractive new ceramic forming process that combines polymer physical chemistry, colloidal chemistry and ceramic technology for making high quality complex-shaped ceramic parts (Young et al., 1991). Slurry made from ceramic powder and a water-based monomer solution is poured into mold, polymerized in-situ to immobilize the particles in a gelled part, removed from the wet mold, then dried and fired. Meth acrylamide (MAM) is the preferred monomer and methylene-bis-acrylamide (MBAM) and polyethylene glycol dimeth acrylate (PEG-DMA) are the preferred cross linkers. Ammonium persulfate (APS) is the free radical initiator (Janney et al., 1998). Factors affecting the performance of ceramic slurries can be summarized as follow: 1 . Solid loading of slurries: The first requirement of the gel casting process is to start from a suspension $>45$ vol. \% solid volume loading (Tari, 2003). 2. Key aspect of dispersant: The dispersion of powder depends upon many factors such as the particles should be wetted by the solvent and be separated from one another and mixed with the solvent system (Singh et al., 2002). Interparticle forces strongly influence suspension behavior because the contact area between particles and the dispersing medium in a colloidal system is very large (Janney, 2015). 3. Premix solution: It consists of solvent, dispersant, monomer, and cross linker. Monomers for gel casting must be water soluble. Monomers should be low in toxicity, and should be inexpensive (Janney, 1998). 4. Kinetics of polymerization: In gel casting, the initiation of polymerization can be determined by changes in temperature of solution (Xiang, 2001). Therefore the idle time $\left(t_{\text {idle }}\right)$ in this system can be determined exactly (Kokabiet et al., 2006). The idle time available for casting the slurry can be controlled by the amounts of initiator and catalyst added to the slurry as well as by the processing temperature (Tong et al., 2004). Polymerization degree was increased with ammonium persulfate used as initiator. To achieve high green strengths an optimum concentration of initiator was necessary to enhance the degree of polymerization. (Potoczek $\boldsymbol{e t}$ al., 2004). Deairing is an essential step in gel casting, this step is occurred 
before gelation and after the addition of initiator to remove both the entrapped air during mixing and also the air dissolved in the solvent phase (Janney et al., 1998), which is difficult to apply in making ceramic molds in situ. A gel casting technology without de-airing process was developed to prepare mullite-based ceramics using silica sol as a binder. In-situ consolidation of the slurry was realized through adjustment of $\mathrm{NH}_{4} \mathrm{Cl}$ concentration as electrolyte to promote gelation of the silica sol in the slurry (Kong et al., 2007).

\section{Starting Materials}

\section{EXPERIMENTAL WORK}

Commercial calcined alumina $\left(\alpha-\mathrm{Al}_{2} \mathrm{O}_{3}\right)$ powder with mean particle size $\leq 10 \mu \mathrm{m}$ was used. The chemical composition is given in Table 1 . Commercial Zirconia powder $\left(\mathrm{ZrO}_{2}\right)$ with particle size of 1-2 $\mu \mathrm{m}$ has been used. NS-30 silica sol (Zhejiang Shangyu Yuda Chemical Engineering Co. Ltd.) was used as non organic binders. Chemical composition of the silica sol is given in Table 2. The electrolyte used is $3.6 \mathrm{~mol}$. $/ \mathrm{L} \mathrm{NH}_{4} \mathrm{Cl}$ solutions as gelling agent.

\section{Experimental procedure}

- Different ceramic batches containing 50\% vol. solid content were used to prepare the ceramic slurries according to the recipe illustrated in Table 3. According to the previous studies (Kong et al., 2007), the recommended solid content of the slurry for gel casting of ceramics was 45 to 65 vol. \%. In this work, the slurry consists of $\mathrm{Al}_{2} \mathrm{O}_{3}$ and $\mathrm{ZrO}_{2}$ powders, inorganic binder and gelling agent.

- The slurries were prepared through directly dispersing the ceramic powders in the silica sol by mechanically stirring using a commercial mechanical mixer for $30 \mathrm{~min}$. The addition of salt with various concentrations can cause a time-dependent gelation of the silica sol. Thus, the gelation time of the slurry was controlled through adjustment of the $\mathrm{NH}_{4} \mathrm{Cl}$ concentration in the slurry, which is $20 \mathrm{~min}$. to avoid sedimentation of the ceramic powders in the silica sol. 
Table 1 Chemical compositions of calcined alumina.

\begin{tabular}{|l|l|}
\hline Oxide & wt.-\% \\
\hline \hline $\mathrm{SiO}_{2}$ & 0.74 \\
\hline $\mathrm{Al}_{2} \mathrm{O}_{3}$ & 98.20 \\
\hline $\mathrm{Fe}_{2} \mathrm{O}_{3}$ & 0.41 \\
\hline $\mathrm{TiO}_{2}$ & 0.23 \\
\hline $\mathrm{CaO}$ & 0.27 \\
\hline $\mathrm{MgO}$ & 0.07 \\
\hline $\mathrm{Na}_{2} \mathrm{O}$ & 0.10 \\
\hline $\mathrm{K}_{2} \mathrm{O}$ & 0.05 \\
\hline Total & $\mathbf{1 0 0 \%}$ \\
\hline
\end{tabular}

- $\quad$ The ceramic slurries were cast in a plastic, or a special varnished wood mold, and left to gel. After gelling, the ceramic slurries were removed from the wet mold, and then dried in an air drier at $250{ }^{\circ} \mathrm{C}$ to remove $95 \%$ of the water content.

- $\quad$ Sintered ceramic bodies were prepared from the gel casted green bodies. The sintering process was occurred at one stage. The ceramic green bodies were fired at $1650{ }^{\circ} \mathrm{C}$ for $2 \mathrm{hrs}$. with heating rate of $5{ }^{\circ} \mathrm{C} / \mathrm{min}$.

- $\quad$ SEM investigations were done in order to examine the microstructure of the sintered ceramic parts. The samples were coated with gold and examined in a Jeol scanning electron microscope JXA-840A, Japan.

Table 2 Compositions and properties of silica sol wt. \%.

\begin{tabular}{||l|l|}
\hline Designation & Specification \\
\hline $\mathrm{SiO}_{2}$ & 30.4 \\
\hline $\mathrm{Na}_{2} \mathrm{O}$ & 0.09 \\
\hline $\mathrm{PH}$ value $\left(20^{\circ} \mathrm{C}\right)$ & 9.3 \\
\hline Density $\left(\mathrm{g} / \mathrm{cm}^{3}\right)$ & 1.203 \\
\hline Viscosity $(\mathrm{mPa} . \mathrm{s})$ & 6.4 \\
\hline Particle size $(\mathrm{nm})$ & 12.0 \\
\hline
\end{tabular}


-EDX analysis was done in order to analyze the phases formed after sintering the ceramic bodies. EDX analyzer determined the elements of the ceramic bodies then, the oxides and phases were calculated.

-Archimedes displacement method was used for determination of the bulk density and apparent porosity. This principle based on soaking the samples under distilled water with boiling for 2 hrs. The saturated samples were weighted $\left(\mathrm{W}_{\mathrm{s}}\right)$ in air and then weighed after immersed in water $\left(\mathrm{W}_{\mathrm{i}}\right)$. The dry weight $\left(\mathrm{W}_{\mathrm{d}}\right)$ was taken after drying the samples overnight at $110^{\circ} \mathrm{C}$. The bulk density (BD) and the apparent porosity (AP) of the samples were calculated according to the following equations respectively,

$$
\begin{aligned}
& B D=\frac{W d}{W s-W i} \times \gamma \\
& A P=\frac{W s-W d}{W s-W i} \times 100
\end{aligned}
$$

Where: $\mathrm{W}_{\mathrm{d}}$ is the dry weight of sample in air, $\mathrm{W}_{\mathrm{s}}$ is the weight of saturated sample in air, $W_{i}$ is the weight of immersed sample in water, and $\gamma$ is the specific gravity of water.

\begin{tabular}{|c|c|c|c|c|c|}
\hline \multicolumn{6}{|c|}{ Batches } \\
\hline \multirow{2}{*}{ Component of Slurry } & A1 & A2 & A3 & A4 & A5 \\
\hline & \multicolumn{5}{|c|}{ wt. \% } \\
\hline Alumina & 70.3 & 65.31 & 60.82 & 52.29 & 44.31 \\
\hline Zirconia & - & 5.22 & 10.2 & 19.74 & 28.68 \\
\hline Silica & 8 & 7.79 & 7.67 & 7.42 & 7.16 \\
\hline Silica Sol. & 29.7 & 29.47 & 28.98 & 27.97 & 27.01 \\
\hline Water & 22.13 & 21.65 & 21.28 & 20.58 & 19.92 \\
\hline Ammonium chloride & $0.1 \mathrm{M}$ & $0.1 \mathrm{M}$ & $0.1 \mathrm{M}$ & $0.1 \mathrm{M}$ & $0.1 \mathrm{M}$ \\
\hline Slurry Density (g/cm³) & 2.26 & 2.31 & 2.35 & 2.43 & 2.51 \\
\hline
\end{tabular}

Table 3 Slurry compositions of gel casting process. 
-Micro hardness of sintered bodies was measured using Digital Micro Hardness Tester (HXD-1000TM). The loading condition was $1000 \mathrm{~kg} / 45 \mathrm{~s}$ and surface-projected diagonals of the indented area were measured by optical microscope. For each sample at least three micro hardness measurements were done.

- Thermal Shock Resistance of the sintered bodies was measured using Muffle Furnace (LM-412.07) with controller G400. The sintered bodies were fired in the furnace at $1000{ }^{\circ} \mathrm{C}$ for 10 minuets, and then quenched in air for 10 minuets.

-Steel, and nodular cast iron polished samples photos were taken using metallurgical microscope Olympus (GX41), and then nodularity of cast iron were calculated by measuring the carbon area using $\mathrm{J}$ micro vision 1.2.7 software from the following equation:

$$
\text { Nodularity } \%=\frac{\text { nodular carbon Area }}{\text { Total carbon area }} \times 100
$$

-Surface roughness was measured using Atomic Force microscope Shimadzu wet-SPM. Plan and 3-D photos of the metal cast surface are taken by the microscope, the surface roughness No. (Ra) is calculated.

\section{RESULTS AND DISCUSSION}

\section{SEM and EDX analysis of sintered ceramic bodies}

Figure 1 shows the SEM image of ceramic bodies sintered at $1650{ }^{\circ} \mathrm{C}$ for 2 hrs. It is appeared that the grains shape of pure alumina is irregular with some equiaxed and faced ones. The high solid loading is accompanied by dense microstructure. From the below figure, it is clear that an incomplete sintering process is occurred. The below figure illuminates that alumina particles is surrounded by silica particles so that mullite phase is existed which will be discussed later. Parts $\left(A_{2}, A_{3}\right.$, and $\left.A_{4}\right)$ show the increased zirconia additions for ceramic bodies. The lower zirconia content is at part $A_{2}$, the higher is at part $\mathrm{A}_{4}$. It is clear that as zirconia increased the porosity of ceramic bodies is increased.

Figure 2 shows the zirconia distribution for 10\% and $20 \%$ volume zirconia content ceramic bodies. The distribution of zirconia is nearly uniform distribution. The good distribution of zirconia particles is very important so that zirconia is the main element come over thermal shock when molten metal is poured in ceramic mold as will be discussed later. 

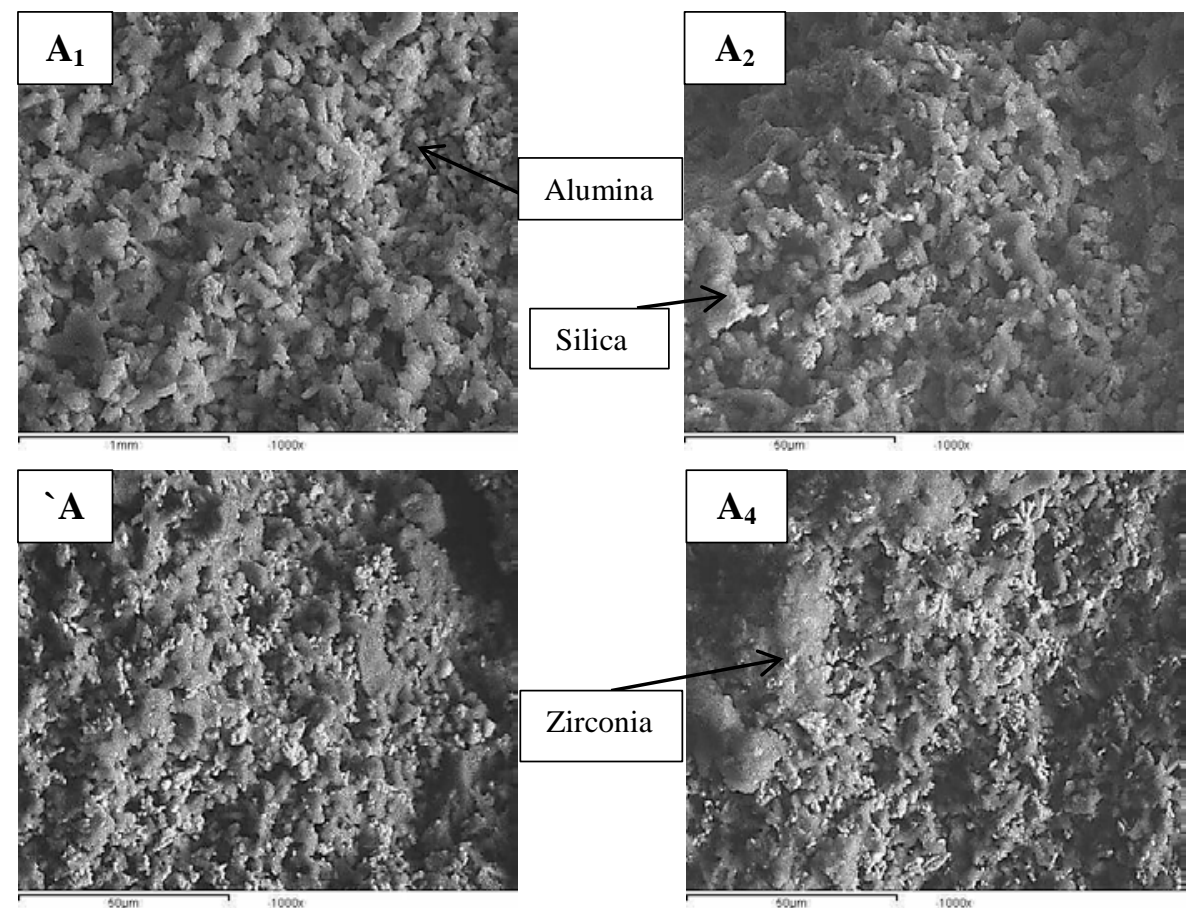

Figure 1 (SEM) photomicrographs for sintered ceramic bodies, where $A_{1}$ ) $0 \%$ $\left.\left.\left.\mathrm{ZrO}_{2}, \mathrm{~A}_{2}\right) 5 \% \mathrm{Zro}_{2}, \mathrm{~A}_{3}\right) 10 \% \mathrm{ZrO}_{2}, \mathrm{~A}_{4}\right) 20 \% \mathrm{ZrO}_{2}$, and $\left.\mathrm{A}_{5}\right) 30 \% \mathrm{ZrO}_{2}$

Table 4 shows the EDX analysis of sintered ceramic bodies, the mapping EDX analysis of $\mathrm{A}_{1}$ sintered ceramic body is explained. The aluminum oxide content is 85.923 wt. \% while the Silicon oxide content is 14.077 wt. \%. This leads to mullite phase formation of $49.70 \mathrm{wt}$. \%, the remained pure alumina is 50.030 wt. \%. The EDX mapping of $\mathrm{A}_{2}$ sintered ceramic body shows that $\mathrm{ZrO}_{2}$ content is 7.180 wt. \%, while $\mathrm{Al}_{2} \mathrm{O}_{3}$ and $\mathrm{SiO}_{2}$ contents are 81.394 wt. \% and 11.426 wt. \% respectively, these ratios lead to $40.555 \mathrm{wt}$. \% of mullite phase, and 52.265 wt. \% pure alumina, the zirconia content remains the same. EDX mapping results of $\mathrm{A}_{3}$ sintered ceramic body shows that zirconia content is reached $11.697 \mathrm{wt}$ \%, otherwise the weight percentage of alumina, and silica reaches to the level of $77.143 \%$, and $10.692 \%$ respectively, the mullite phase content is $37.957 \mathrm{wt}$ \% while the free alumina percentage is $49.878 \mathrm{wt}$. $\%$. EDX mapping of $\mathrm{A}_{4}$ sintered ceramic body. The zirconia content 20.553 wt. \%, while the alumina content reaches the level of $69.584 \mathrm{wt}$. \%. The silica weight percent is $9.858 \%$ leading to a mullite phase of $34.996 \mathrm{wt}$. \%, the remained free alumina is $44.447 \mathrm{wt}$. \%. EDX mapping of $\mathrm{A}_{5}$ sintered ceramic body explains that zirconia reaches to $27.294 \%$. Alumina content is 63.023 wt. \%, while the silica level is 9.684 wt. \%. The mullite phase formed is 34.378 wt. \%, leaving only a 38.332 wt. \% of free alumina. 


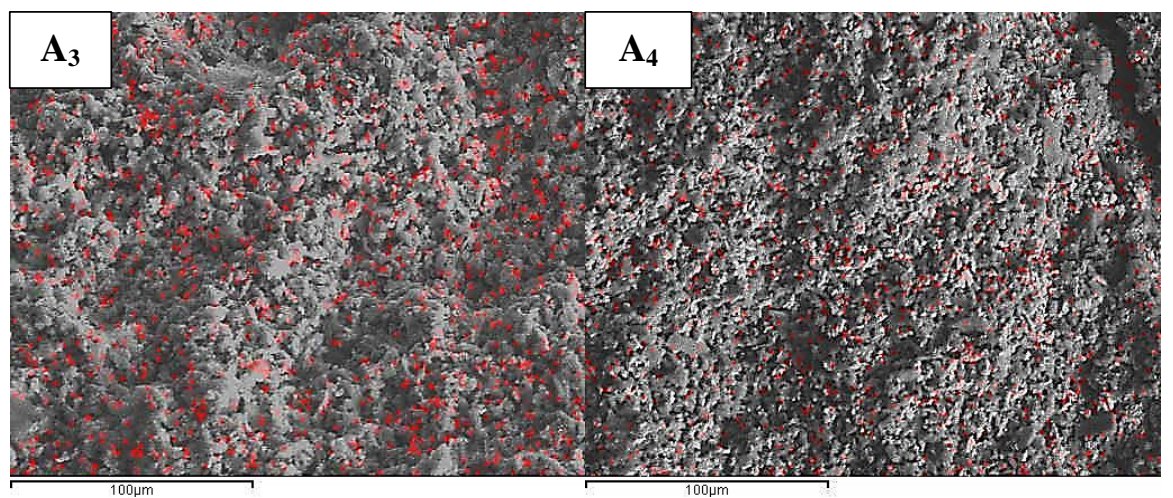

Figure 2 Zirconia distributions in sintered ceramic bodies, where $A_{3}$ ) 10\% $\mathrm{ZrO}_{2}$, and $\mathrm{A}_{4}$ ) $20 \% \mathrm{ZrO}_{2}$ respectively.

Table 4 EDX mapping of sintered ceramic bodies

\begin{tabular}{|l|l|l|l|l|l|l|}
\hline \multirow{2}{*}{$\begin{array}{l}\text { Ceramic } \\
\text { sample }\end{array}$} & \multicolumn{3}{|c|}{ Oxides } & \multicolumn{3}{c|}{ Phases } \\
\cline { 2 - 8 } & $\mathbf{A l}_{\mathbf{2}} \mathbf{O}_{\mathbf{3}}$ & $\mathbf{S i O}_{\mathbf{2}}$ & $\mathbf{Z r O}_{\mathbf{2}}$ & Alumina & Mullite & Zirconia \\
\hline $\mathbf{A}_{\mathbf{1}}$ & 85.923 & 14.077 & --- & 50.030 & 49.970 & --- \\
\hline $\mathbf{A}_{\mathbf{2}}$ & 81.394 & 11.426 & 7.180 & 52.265 & 40.555 & 7.180 \\
\hline $\mathbf{A}_{\mathbf{3}}$ & 77.143 & 10.692 & 11.697 & 49.878 & 37.957 & 11.697 \\
\hline $\mathbf{A}_{\mathbf{4}}$ & 69.584 & 9.858 & 20.553 & 44.447 & 34.996 & 20.553 \\
\hline $\mathbf{A}_{\mathbf{5}}$ & 63.023 & 9.684 & 27.294 & 38.332 & 34.378 & 27.294 \\
\hline \hline
\end{tabular}

\section{Physical and Mechanical properties of sintered ceramic bodies}

The determination of sintering parameters in terms of bulk density, apparent porosity of the fired samples was carried out. It should be mentioned that porosity and density of any ceramic materials reflect the good degree of textural homogeneity, compactness and low permeability of the body to gases and fluid. Figures (3 and 4) show the sintering parameters of gel casted samples after sintering at $1650{ }^{\circ} \mathrm{C}$ for $2 \mathrm{hrs}$.

All gel casted samples showed an increase in sintered density. The increase of bulk density is due to the increase in Zirconia content which has high density $\left(6 \mathrm{~g} / \mathrm{cm}^{3}\right)$ compared with Alumina $\left(3.79 \mathrm{~g} / \mathrm{cm}^{3}\right)$. The bulk density of $0 \%$ zirconia content is $2.35 \mathrm{~g} / \mathrm{cm}^{3}$ which increase up to $2.8 \mathrm{~g} / \mathrm{cm}^{3}$ in the $30 \%$ zirconia content ceramic sintered body. This increase is quite low to affect the mechanical properties of the bodies.

The apparent porosity increases with the zirconia content. The apparent porosity is $26.36 \%$ at $0 \%$ zirconia content ceramic body, while the largest apparent porosity is $37.87 \%$ at $30 \%$ zirconia content. This may be attributed to the tetragonal to monoclinic phase transformation of zirconia particles, which limits the sintering and grain growth of alumina-silica upon firing at 
$1650{ }^{\circ} \mathrm{C}$. Also, the thermal mismatch in the thermal expansion coefficients between the different phases within the composite (alumina, mullite, $\mathrm{t}$ zirconia, and m-zirconia) enhances the Nano pores formation in the ceramic composites matrix (Wahsh et al., 2012).

Figure 5 shows the hardness for sintered ceramic bodies, the sample prepared by $100 \%$ alumina and $0 \%$ zirconia gives higher hardness as compared with other slurries. On the other hand, the sample prepared by $70 \%$ alumina and $30 \%$ zirconia gave the lower hardness. The higher hardness of $0 \%$ zirconia sample is due to the lower apparent porosity that improves the mechanical properties. The highest hardness measured for $0 \%$ zirconia samples is around 678.16 HV and the lowest value for $30 \%$ zirconia samples is around 579.28 HV. For increased zirconia, the micro hardness decreases because of formation of Nano pores which decreases the mechanical properties of the ceramic slurries; also quite low bulck densities affect these results.

Cold crushing strength of ceramic bodies sintered at $1650{ }^{\circ} \mathrm{C}$ for 2 hrs. is observed in Figure 6, the ceramic sample with $0 \%$ zirconia gives the higher CCS value (251 Mpa), while that of 30\% zirconia content gives the lower CCS value $(180 \mathrm{Mpa})$. This is due to the relatively higher surface area of silica Nano powders to volume ratio, which enhances the contact of Nano grains through grain boundaries and leads to the strongly tight of the particles on firing. Also, the CCS decreases with phase transformation of zirconia from tetragonal to monoclinic micro structure which increases the porosity of the ceramic composites with zirconia content. Actually, the increasing porosity has a deleterious effect on the mechanical properties (Wahsh et al., 2012).

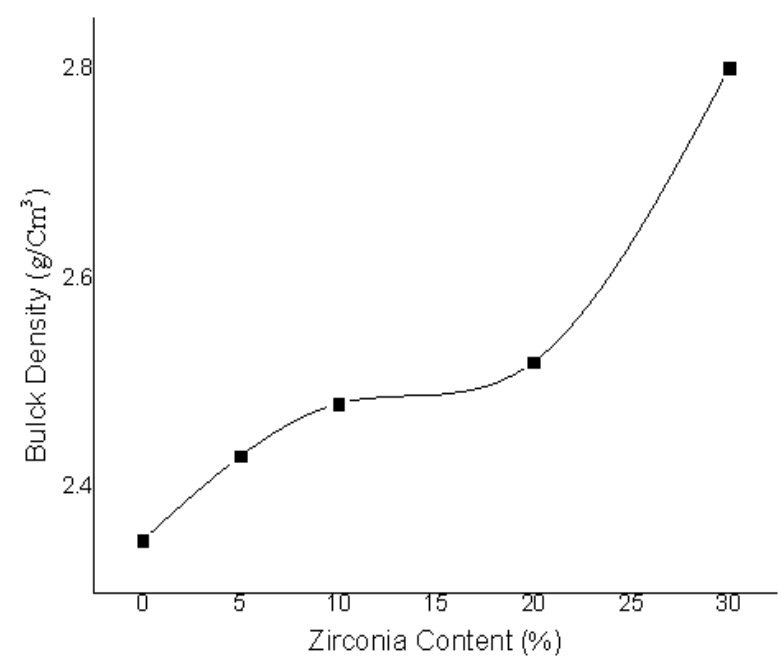

Figure 3 Bulck densities of sintered ceramic bodies. 


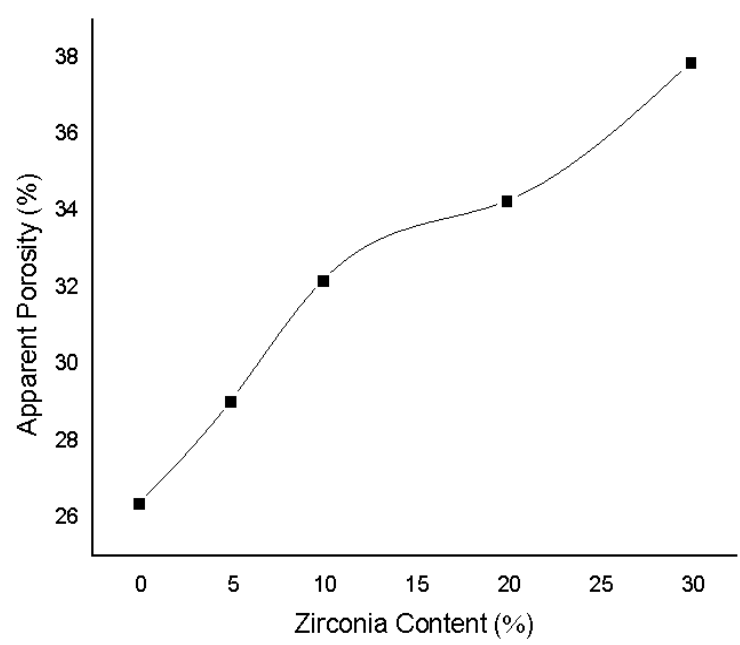

Figure 4 Apparent porosities of sintered ceramic bodies.

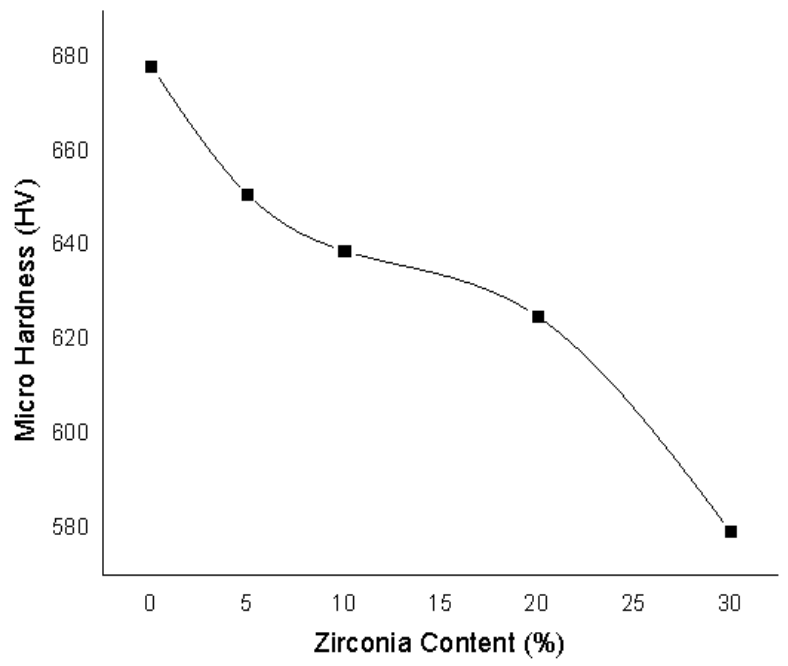

Figure 5 Micro harnesses of sintered ceramic bodies. 


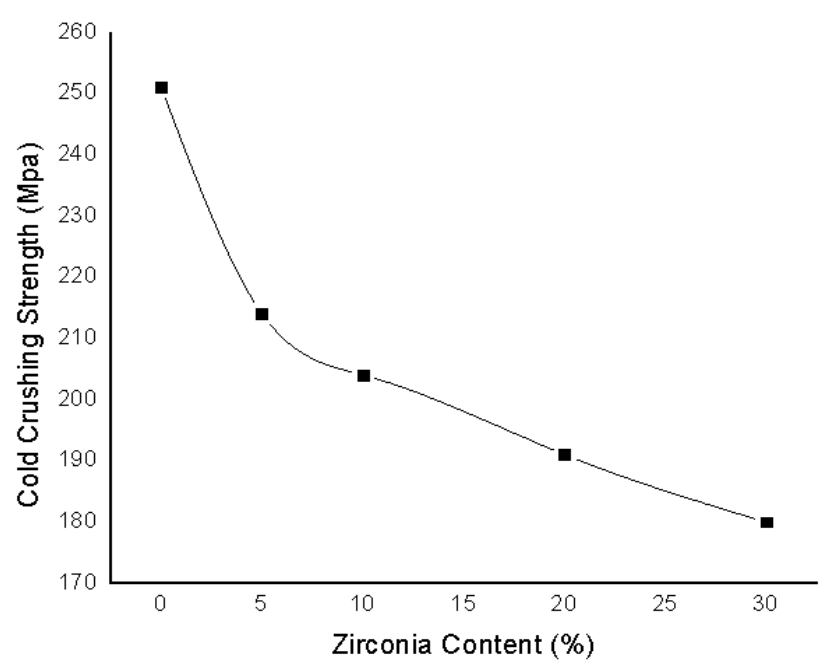

Figure 6 Cold crushing strengths of sintered ceramic bodies.

Thermal shock resistance of sintered ceramic bodies sintered at $1650{ }^{\circ} \mathrm{C}$ is shown in Figure 7. 30\% zirconia ceramic sample gives the best thermal shock resistance (20 cycles). It is known that ceramic pure phases cannot sustain thermal shock but in this case, there is a composite matrix of alumina (38.332 wt. \%), mullite (34.378 wt. \%), and zirconia (27.294 wt. \%). The mismatch in the thermal expansion coefficients of the constituent phases; $\alpha$-alumina $(8.2 \times$ $\left.10^{-6} \mathrm{~K}^{-1}\right)$, mullite $\left(4.5 \times 10^{-6} \mathrm{~K}^{-1}\right)$, m-zirconia $\left(6.5 \times 10^{-6} \mathrm{~K}^{-1}\right)$, and t-zirconia $\left(10.5 \times 10^{-6} \mathrm{~K}^{-1}\right)$ as well as the tetragonal to monoclinic transformation of zirconia, which is accompanied by volume increase have a good effect on thermal shock resistance. The development of a micro crack on thermal shock with zirconia gives the necessary space for the phase transformation to occur which results in stopping of crack propagation; also, the increase of porosity reduces the heat transfer in the ceramic composites matrix (Wahsh et al., 2012).

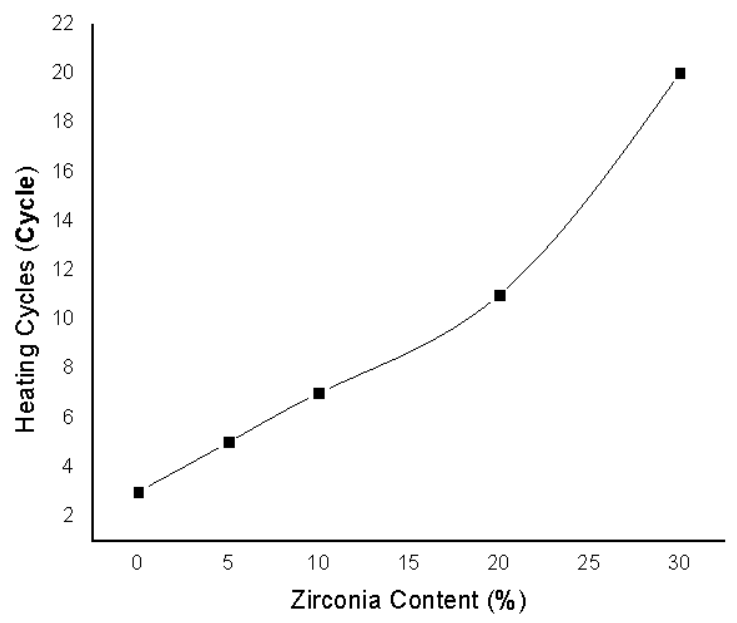

Figure 7 Thermal shock resistances of sintered ceramic bodies 


\section{Preparing of a ceramic casting mold}

The ceramic casting mold is made using the ceramic gel casting process using silica sol as a binder. The following steps describe the ceramic mold preparing.

\section{Slurry preparing and pouring}

The ceramic mold slurry is prepared through directly dispersing the ceramic powders (70\% alumina, and 30\% zirconia as refractory) in the silica sol by mechanically stirring using a commercial mechanical mixer for 30 minuets. At $\mathrm{pH}$ above 7 but lower than 11, it was found that ammonium ions were efficient in destabilizing silica colloidal particles. The addition of salt with various concentrations can cause a time-dependent gelation of the silica sol. Thus, the gelation time of the slurry is controlled through adjustment of the $\mathrm{NH}_{4} \mathrm{Cl}$ concentration in the slurry $(0.1 \mathrm{M} / \mathrm{L})$. The gelling time was adjusted to be 20 minuets to avoid sedimentation of the ceramic powders in the silica sol. After mixing, the ceramic slurry is cast in a special varnished wood mold, and left to gel. After gelling, the ceramic slurry is removed from the mold while still wet, before the mold is dried.

If the ceramic green body is left to dry in the mold a crack will appear in the mold as will be discussed. The draft allowance of pattern is the same as patterns used for sand casting, the binder used is colloidal silica, which makes the mold to stick on the pattern surface. The draft allowance is designed as the allowances used for sand casting to help the mold extraction from the pattern, as well as a lubricant (oil, or liquid soap, or Vaseline) is used to eliminate the adhesive forces between the mold and pattern surface.

\section{Defects in ceramic molds}

Three defects were discovered when preparing the ceramic mold using gel casting method, these defects are as follows:

\section{- Crack appearance in gelled ceramics}

Figure 8 shows the cracks in ceramic gelled parts, the ceramic mold should be extracted from the mold after gelation but when the mold is still wet. If the ceramic gel is left to dry in the mold a crack will appear in the mold. As further water is removed from the green body network, three-dimensional free shrinkage occurs. This is due to a compressive surface force being developed by the water remaining in the capillaries of the green body. Ceramic green body is produced from a mixture of large ceramic particles and small silica particles, which contain fewer capillaries, reduce stresses within the network that can produce fractures. If the ceramic mold is left to dry in the pattern the reaction of the pattern to the compressive force will convert the shrinkage from a free to forced shrinkage, which will produce stresses on the mold. The 
stresses will concentrate in the corners of the pattern producing crack initiation and propagation in these points as shown.

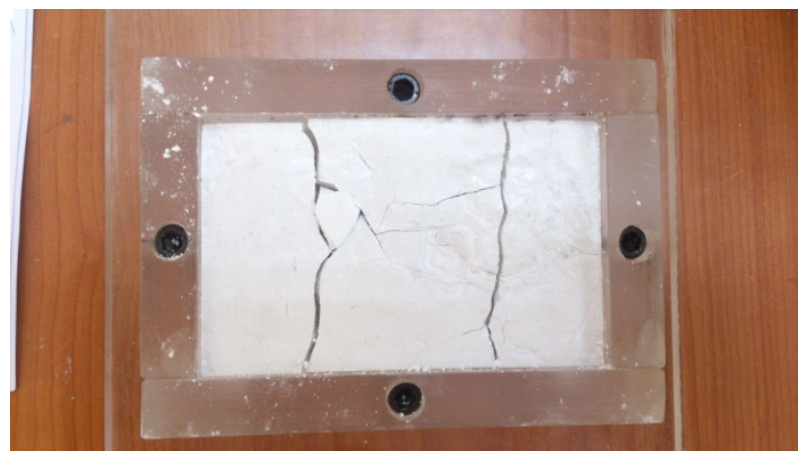

Figure 8 Crack appearances in gelled ceramics

\section{- Improper gelling behavior}

Figure 9 shows the improper gelling behavior of ceramic green body. The gelation of a silica sol is the formation of three dimensional networks of continuous particles of colloidal silica. If the negative charge preventing the particles from colliding is reduced by adding an electrolyte the silica particles will come into contact and polymerize, then some of these polymerized particles aggregate into short chains. As the chain length increases, particles added to both the sides and the ends of the chains. Thus, a region of branched chains is created. Free particles within this region are added to the network, forming a 'micro gel region' of 'gelled' silica. Each micro gel region increases in size until gel phase occupies much of the total volume. At this point the gel regions grow together into a continuous coherent network.

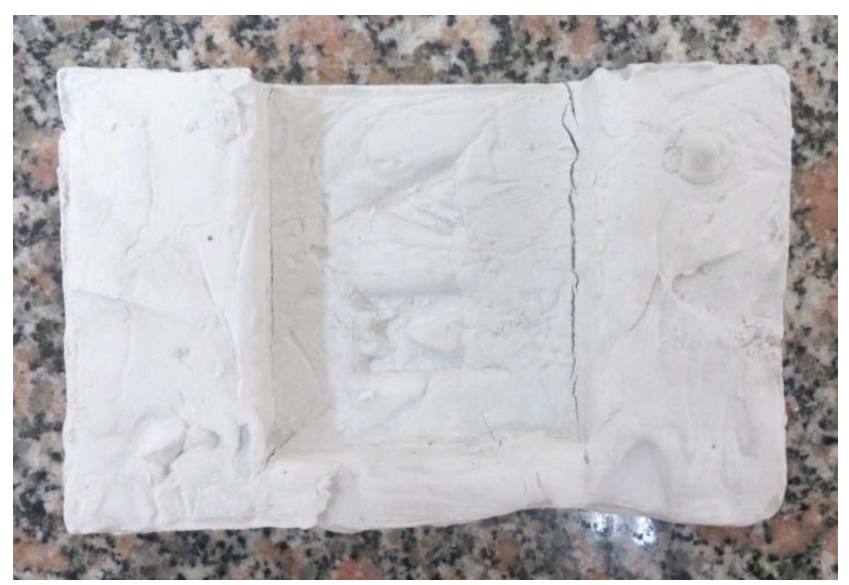

Figure 9 Improper gelling behaviors

In ceramic molds the wall thickness may not be equal, so the time taken to form the micro gel region will differ from wall to another. The gelling agent must be good mixed to make sure that the short chains will be created into the whole slurry, so the gelation time will be equal. If not, the improper gelling 
behavior will occur as shown in Figure 9. The green body shown has a complete gelled part at the left and an incomplete gelled part at the right marked by the finger print. To overcome this problem, the slurry must be mixed in a wide plate to increase the area affected in the gelling agent added and mix it quickly before pouring into the mold.

\section{- Improper surface cracks}

Figure 10 shows a ceramic gelled part with excess silica ratio. The ceramic slurry is calculated to have $50 \%$ by volume water, $40 \%$ by volume refractory, and $10 \%$ by volume silica to achieve the condition of high volume solid loading. Silica and water come from the silica sol, which has a calculated ratio. If the silica sol ratio is increased, the gelling agent ratio will decrease as the gelling time will increase. Increasing gelling time will cause sedimentation of ceramic powder and silica to float over the surface. After gelation, the free silica sol gelation mechanism will cause surface cracks shown.

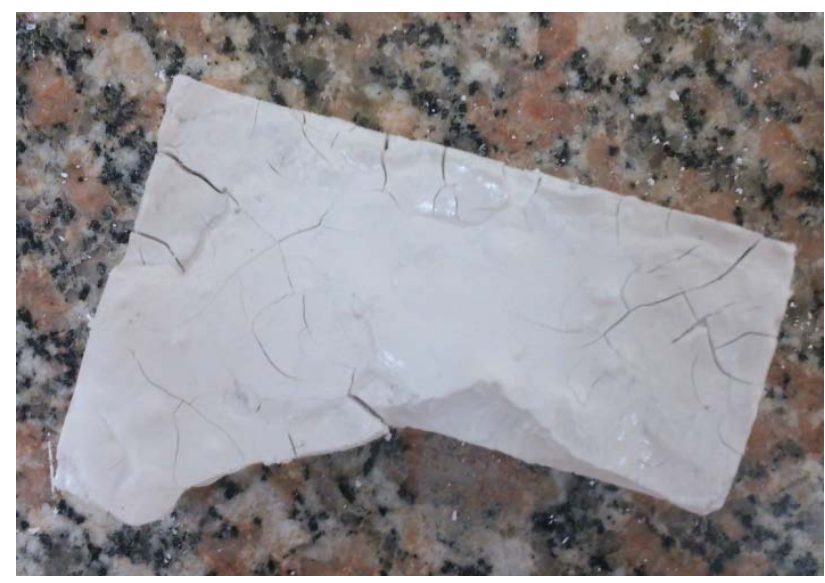

Figure 10 Improper surface cracks

\section{Sintering of ceramic green mold}

When a polymer binder is used (acrylamide) in gel casting, the firing process is occurred at two stages. The first stage is removing of the binder. A typical binder removal schedule was done by heat the ceramic parts at $600^{\circ} \mathrm{C}$ at heating rate of $3{ }^{\circ} \mathrm{C} / \mathrm{min}$. The second stage of firing is the sinterability of ceramic bodies. Sintering of the ceramic parts was done at $1650^{\circ} \mathrm{C}$ in air for 2 hrs. When silica sol is used as a binder, polymer was not removed from the green bodies so that the sintering process was occurred at one stage. After gelation, the ceramic green body is dried in electrical drier. The water must be dried slowly before firing to eliminate cracks occurred due to high surface compressive forces due to shrinkage.

After that, the ceramic dried bodies were fired at $1650{ }^{\circ} \mathrm{C}$ for $2 \mathrm{hrs}$. with a heating rate of $5{ }^{\circ} \mathrm{C} / \mathrm{min}$. to be sintered and to allow mullite formation. After 
sintering no significant change in dimensions is noticed because of high solid loading of ceramic powders, and the tetragonal to monoclinic phase transformation of zirconia which increases the volume by (4-5) \%. This increase in volume compensates the volume shrinkage due to water losses at drying stage.

\section{4. $\quad$ Pouring the metal into the mold}

The sintered mold is then taken to the foundry to the metal poured in. The metals poured into the ceramic mold are carbon steel at $1600{ }^{\circ} \mathrm{C}$, and nodular cast iron at $1450{ }^{\circ} \mathrm{C}$. The mold is preheated up to 500 to $600{ }^{\circ} \mathrm{C}$ using direct flame or in an open air furnace to reduce the thermal shock effect into the mold. The mold is surrounded by bonded mold sand to keep it at the required temperature as known that the sand can store heat when heated and looses after the mold is taken out from the furnace. The mold will cool down from the outside surface to the inside of the mold.

\section{Surface roughness measurements}

Figure 11 shows the plan image for metal cast surface poured in (A) sand mold, (B) ceramic mold. The plan image of sand mold cast shows that the surface has peaks and valleys which affect the surface roughness of the cast metal when measured, while the plan image of the ceramic mold cast shows that the surface has a smooth texture leading to a very fine surface roughness. Figure 12 shows the 3-D images for sand mold and ceramic mold metal cast showing the differences between the two surfaces, the ceramic mold metals cast has a smooth texture. Surface roughness is interconnected and linked with the mold surface roughness, because of the ceramic mold is made of fine powder the surface roughness of the metal cast is finer than that of sand mold. The surface roughness number $R_{a}$ of the metal cast into ceramic mold is 0.582 $\mu \mathrm{m}$, while of the metal cast into sand mold is $5.187 \mu \mathrm{m}$.

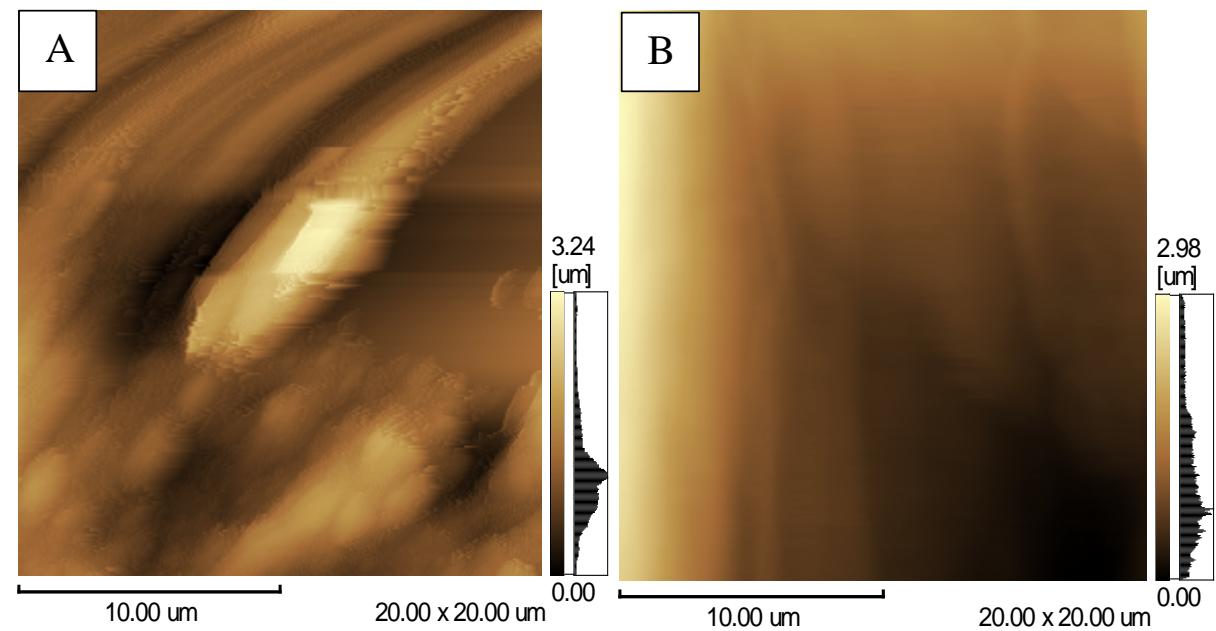

Figure 11 Plan image of metal cast surface poured in: (A) sand mold, (B) ceramic mold. 


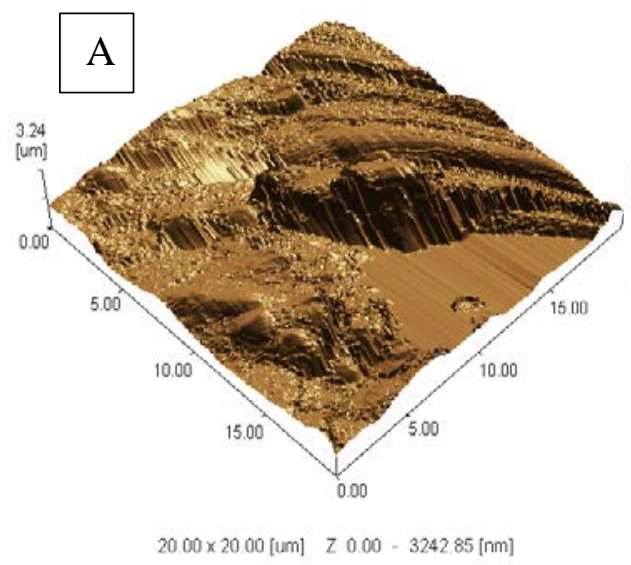

$20.00 \times 20.00[u m] \quad Z 0.00-3242.85[\mathrm{~nm}]$

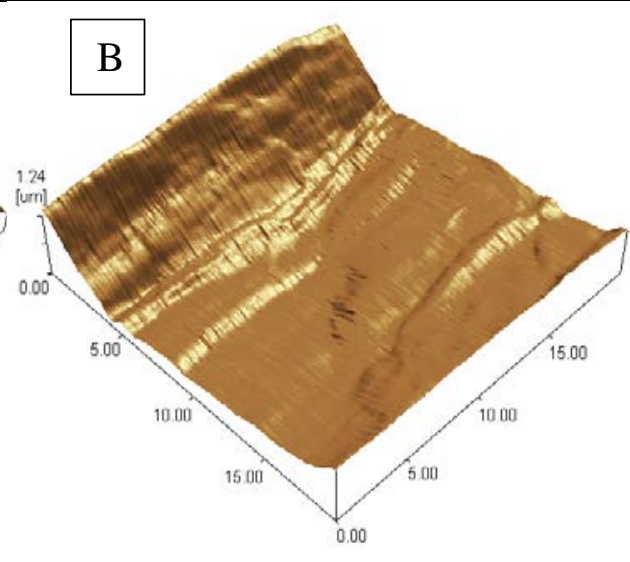

$2000 \times 2000[\mathrm{um}] \quad Z 000-123806[\mathrm{~nm}]$

Figure 12 3-D image of metal cast surface poured in: (A) sand mold, (B) ceramic mold.

\section{CONCLUSION}

Based on the results of the experimental investigation, the following conclusions are drawn:

1. A new ceramic mold may be fabricated by gel casting method. The ceramic mold consists of an alumina-mullite-zirconia matrix with the ratios of 38.332 wt. \% of alumina, 34.378 wt. \% of mullite, and 27.294 wt. \% of zirconia respectively.

2. Bulk density and apparent porosity for ceramic mold are $2.8 \mathrm{~g} / \mathrm{cm}^{3}$ and $37.87 \%$ respectively, leading to higher mold permeability which is important to eliminate trapping of residual gases.

3. The micro hardness and the cold crushing strength of ceramic mold are 579.28 HV and 180 Mpa respectively, the thermal shock resistance is 20 cycles because of tetragonal to monoclinic phase transformation during sintering.

4. There are three main defects in the mold fabrication process. The 1st defect is the mold cracking, which is a result of forced shrinkage of mold in pattern. The 2nd defect is the improper gelling behavior, equal gelling time. The last defect is the improper surface cracks, which a result of increased silica ratio added to the mixture .

5. The metal is poured into the mold with preheating temperature of 500 to $600{ }^{\circ} \mathrm{C}$ to eliminate the cold start effect, and to reduce the thermal shock.

6. The pattern is applicable for nodular cast iron so that the mold is hard enough to withstand the forces resulting from spheroidal graphite formation when nodular cast iron is poured into the ceramic mold.

7. The surface roughness No. of metal cast into ceramic mold is $0.582 \mu \mathrm{m}$, while of the metal cast into sand mold is $5.187 \mu \mathrm{m}$. 


\section{REFERENCES}

Young, A.; Omatete, O.; Janney, M.; and Menchhofer, P. (1991): Gel casting of alumina, J. Am. Ceram. Soc. 74(3), pp. 612-618.

Singh, B.; Bhattacharjee, S.; and Besra, L. (2002): Influence of surface charge on maximizing solids loading in colloidal processing of alumina, Mater. Lett. 56 p. 475.

Kong, D.; Yang, H.; Wei, S.; Li, D.; and Wang, J. (2007): Gel-casting without de-airing process using silica sol as a binder, Ceram. Internat. 33, pp. 133-139.

Mills, D. (1992): Ceramic mold material, US Pat. No. 5,143,777.

Tari, G. (2003): Gelcasting ceramics: A review, J. Am. Ceram. Soc. Bul., 82(4), pp. 43-46.

Jack, H. (2001): Manufacturing processes, special notes available at http://claymore.engineer.gvsu.edu. p. 252.

Bralla, J. (2007): Handbook of manufacturing processes, First Edition, pp. 20-22.

Tong, J.; and Chen, D. (2004): Preparation of alumina by aqueous gel casting, Ceram. Internat. 30, pp. 2061-2066.

Xiang, J.; Xie, Z.; and Huang, Y. (2002): Processing of $\mathrm{Al}_{2} \mathrm{O}_{3}$ sheets by the gel-tape-casting process, Ceram. Internat. 28, pp. 17-22.

Janney, M.; Nunn, S.; Walls, C.; Omatete, O.; Ogle, R.; Kirby, G.; and McMillan, A. (1998): Gel casting, Handbook of ceramic engineering, Marcel Dekker, pp. 1-15.

Janney, M.: Attaining high solids in ceramic slurries, available at. http: // www. Researchgate.net, accessd at Feb 22, 2015.

Janney, M.; Omatete, O.; Walls, C.; Nunn, S.; Ogle, R.; and Westmoreland, G. (1998): Development of low-toxicity gel casting systems, J. Am. Ceram. Soc., 81, pp. 581-591.

Kokabiet, M.; Babaluo, A.; and Barat, A. (2006): Gelation process in lowtoxic gel casting systems, J. Euro. Ceram. Soc. 26, pp. 3083-3090.

Potoczek, M.; and Zawadzak, E. (2004): Initiator effect in the gel casting properties of alumina in a system involving low-toxic monomers, Ceram. Internat. 30, pp. 793-799.

Wahsh, M.; Khattab, R.; Awaad, M.; (2012): Thermo mechanical properties of mullite/zirconia reinforced alumina ceramic composites, Mat. Des. 41, pp. 3133.

Beeley, P. (2001): Foundry technology, Second edition, pp. 568 - 569.

Böllinghaus, T. (2009): Springer handbook of mechanical engineering, Springer, pp. $542-543$.

Piwonka, T. (1998): ASM Handbook, (Volume 15) Ninth Edition, pp. 535 543. 


\title{
تصنيع قالب جديد لسباكة المعادن بطريقة سباكة الجل باستخدام محاليل السيليكا كمادة رابطة
}

\author{
محمود فرج محمود زوره (')، سيد عبد الونيس عبداله (Y)، ريهام محمد خطاب (')، ابر اهيم موسى ابر اهيم (Y)، وليد

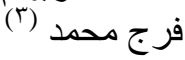 \\ (1) المركز القومى للبحوث، قسم الحر اريات و السير اميك.

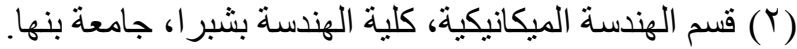

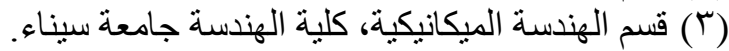

يقدم هذا البحث طريقة جديدة لعمل القو الب السير اميكية باستخدام طريقة سباكة الجل باستخدام محلول

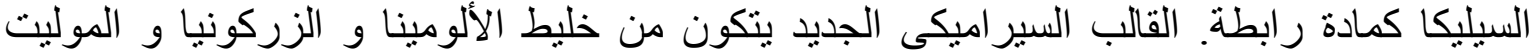

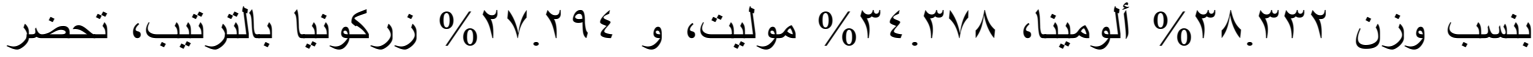

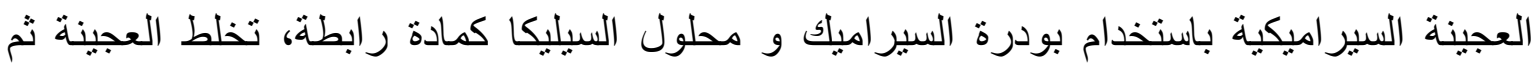

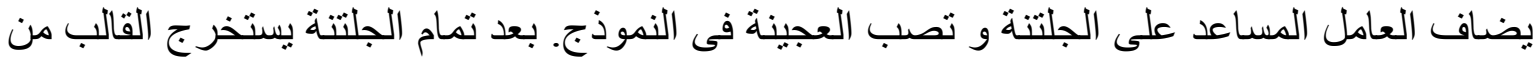

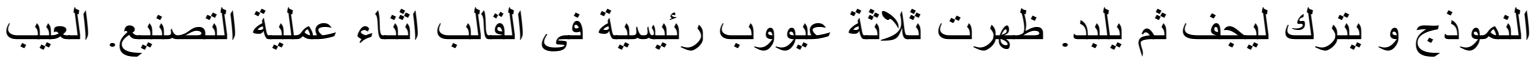

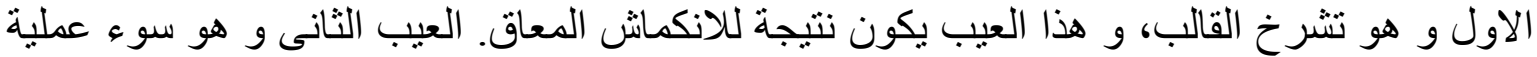

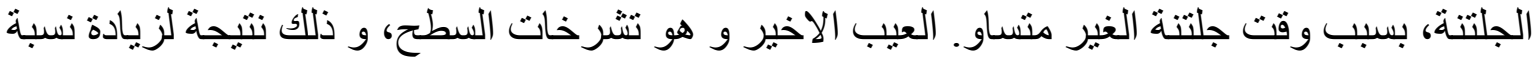

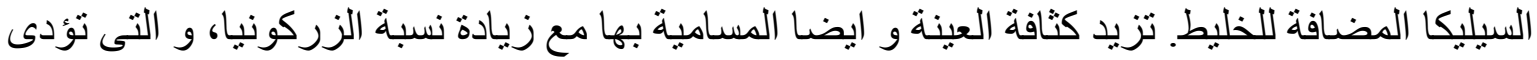

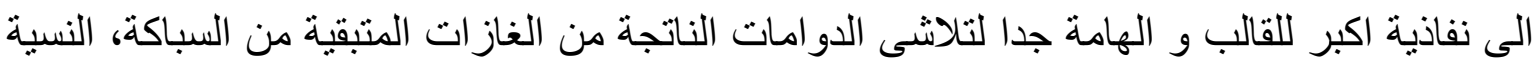

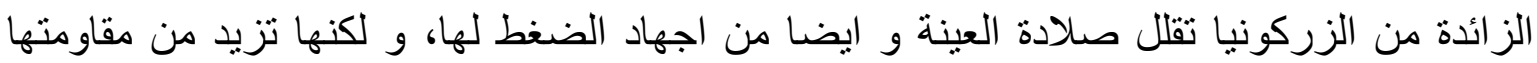

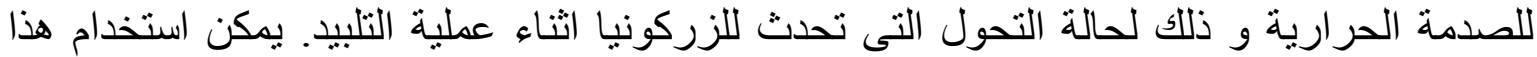
القالب فى سباكة حديد الزهر الكروى و ذللك لقدرته على تحمل القوى الناتجة من تكون الفحسال

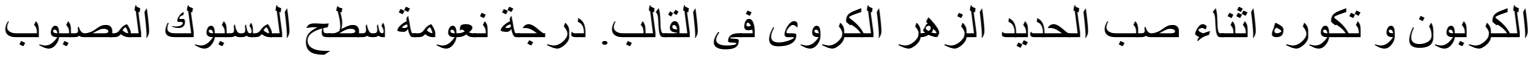

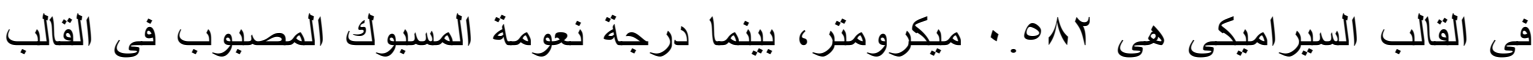

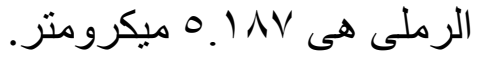

